\title{
KENDALA GURU DALAM PENYELENGGARAAN PENILAIAN SIKAP
}

\author{
I. K. Sudiana ${ }^{1}$, I. D. K. Sastrawidana ${ }^{2}$, N. P. S. Antari ${ }^{3}$ \\ Universitas Pendidikan Ganesha \\ Singaraja, Indonesia
}

e-mail: sudi.ana@undiksha.ac.id, ketut.sastrawidana@undiksha.ac.id, sariantari23@gmail.com

\begin{abstract}
Abstrak
Penelitian ini bertujuan untuk mengetahui penilaian sikap sebagai dampak pengiring pembelajaran kimia. Penelitian ini menggunakan jenis penelitian kualitatif dengan pendekatan fenomenologi. Subjek dalam penelitian ini adalah guru kimia. Aktivitas dalam penelitian ini yaitu penilaian sikap yang dilaksanakan oleh guru meliputi aspek perencanaan, pelaksanaan, penilaian, dan pengawasan. Metode pengumpulan data yang digunakan dalam penelitian ini adalah observasi, wawancara, dan studi dokumen. Data penelitian ini dianalisis menggunakan teknik kualitatif deskriptif. Teknik pemeriksaan keabsahan data dalam penelitian ini adalah menggunakan dua teknik triangulasi yaitu triangulasi sumber dan metode. Hasil penelitian ini menunjukkan bahwa, (1) guru kimia menyusun perencanaan penilaian sikap dengan mencantumkan semua sikap spiritual dan sikap sosial, serta merencanakan penilaian observasi, penilaian diri, dan penilaian antarteman. Namun mengalami hambatan dalam pelaksanaan sehingga tidak semua perencanaan penilaian sikap dapat dilakukan, (2) pada pelaksanaan guru melaksanakan pembelajaran tidak langsung yang berdampak pada pembentukan karakter siswa yang dilakukan dengan keteladanan, nilai karakter yang dimunculkan yaitu religius, toleran, disiplin, jujur, kerjasama, tanggung jawab, percaya diri, dan santun sedangkan guru menilai sikap hanya empat aspek nilai karakter yaitu tanggung jawab, rasa ingin tahu, disiplin, dan jujur, (3) penilaian sikap yang dilaksanakan oleh guru hanya menggunakan penilaian observasi dengan jurnal sedangkan penilaian antarteman dan penilaian diri tidak dilakukan karena hasil penilaian antarteman dan penilaian diri tidak sesuai dengan penilaian observasi yang dilaksanakan oleh guru saat pembelajaran, (4) proses pengawasan yang dilakukan didapatkan bahwa guru kimia mengalami kesulitan melakukan penilaian sikap karena instrumen yang berubah- ubah, jumlah siswa yang banyak, dan karakter siswa yang berbeda-beda.
\end{abstract}

Kata kunci: penilaian sikap, dampak pengiring, karakter.

\begin{abstract}
This study aims to determine the assessment of attitude as an impact of chemistry learning accompaniment. This research uses qualitative research with a phenomenological approach. The subjects in this study were chemistry teachers. Activities in this
\end{abstract}


research are attitude assessment carried out by teachers including aspects of planning, implementation, evaluation, and supervision. Data collection methods used in this study were observation, interviews, and document studies. The data of this study were analyzed using descriptive qualitative techniques. The data validity checking technique in this research is to use two triangulation techniques, namely source and method triangulation. The results of this study indicate that, (1) the chemistry teacher prepares an attitude assessment plan by listing all spiritual attitudes and social attitudes, as well as planning observations, self-assessments, and interpersonal assessments. But experience obstacles in implementation so that not all attitude assessment planning can be done, (2) the implementation of the teacher implements indirect learning that impacts on the formation of student character which is done by example, the character values that appear are religious, tolerant, disciplined, honest, cooperation, responsibility, confidence, and courtesy while the teacher assesses the attitude of only four aspects of character values, namely responsibility, curiosity, discipline, and honesty, (3) the attitude assessment carried out by the teacher only uses observation observation with journals while interpersonal assessment and assessment self is not done because the results of peer assessment and self-assessment are not in accordance with the assessment of observations carried out by the teacher during learning, (4) the monitoring process carried out found that chemistry teachers had difficulty doing attitudes because of changing instruments, the large number of students, and character s different iswa.

Keywords: attitude assessment, accompaniment impact, character

\section{PENDAHULUAN}

Berdasarkan Permendikbud No. 20 Tahun 2018 pasal 2 menyebutkan bahwa PPK dilaksanakan dengan menerapkan nilai-nilai Pancasila dalam pendidikan karakter terutama meliputi nilai-nilai religius, jujur, toleran, disiplin, bekerja keras, kreatif, mandiri, demokratis, rasa ingin tahu, semangat kebangsaan, cinta tanah air, menghargai prestasi, komunikatif, cinta damai, gemar membaca, peduli lingkungan, peduli sosial, dan bertanggung jawab. berdasarkan hasil Survey National Association of Colleges and Employee (NACE, 2002) dalam Elfindri dkk (2011:156) terdapat 16 dari 19 kemampuan yang diperlukan adalah soft skills sehingga soft skills sangat penting diberikan dalam proses pendidikan, soft skills dapat menentukan arah pemanfaatan hard skills. Jika seseorang memilikinya dengan baik, maka ilmu dan keterampilan yang dikuasainya dapat mendatangkan kesejahteraan dan kenyamanan bagi pemiliknya dan lingkungannya. Sebaliknya, jika seseorang tidak memiliki soft skills yang baik, maka hard skills dapat membahayakan diri sendiri dan orang lain. dengan hasil penelitian yang dilakukan oleh Ratnawati (2016) yang menunjukkan bahwa terdapat kontribusi positif antara variabel pendidikan karakter terhadap soft skills dengan signifikansi sebesar $19,1 \%$, pendidikan karakter memiliki kontribusi positif terhadap soft skills siswa yang memiliki makna pendidikan karakter seorang siswa baik maka akan diikuti dengan soft skills yang baik. Akan tetapi, Mazzola (2003) melakukan survei tentang bullying (tindak kekerasan) di sekolah. Hasil survei menunjukkan; (1) setiap hari sekitar 160.000 siswa mendapatkan tindakan bullying di sekolah, 1 dari 3 responden yang diteliti (siswa pada usia 18 tahun) pernah mendapatkan tindakan kekerasan, 75-80\% siswa pernah mengamati tindak kekerasan, $15-35 \%$ siswa adalah korban kekerasan dari tindak kekerasan maya (cyberbullying). Idealnya, pendidikan harus mampu memberikan pencerahan dan menumbuhkan sikap spiritual dan sikap sosial kepada siswa, sehingga siswa mampu bersikap responsif terhadap segala persoalan yang dihadapi. Melalui pendidikan karakter yang ada pada $\mathrm{KI}-1$ dan $\mathrm{KI}-2$, siswa dapat menjadi sosok yang memiliki apresiasi tinggi terhadap masalah kemanusiaan, kejujuran, 
demokratis, toleransi, dan kedamaian hidup. Tetapi fakta di lapangan menunjukkan masih banyak guru yang mengalami kesulitan dalam mengimplementasikan penilaian pada $\mathrm{KI}-1$ dan $\mathrm{KI}-2$ sehingga berdampak terhadap pengembangan karakter pada siswa. Rendahnya penanaman nilainilai karakter yang terdapat pada $\mathrm{KI}-1$ dan $\mathrm{KI}-2$ menyebabkan pemerosotan karakter pada siswa. Hal ini didukung dengan hasil penelitian yang dilakukan oleh Ariantini, dkk., (2014) dinyatakan bahwa guru mengalami hambatan dalam menghadapi pengintegrasian sikap spiritual dan sikap sosial dalam pembelajaran meliputi tidak adanya pedoman yang pasti tentang pengintegrasian sikap spiritual dan sikap sosial dan hambatan pelaksanaan yang terletak pada karakter setiap siswa yang berbeda-beda, sehingga menyulitkan guru dalam mengimplementasikan pengintegrasian sikap spiritual dan sikap sosial dalam kegiatan pembelajaran.SMA Negeri 3 Singaraja merupakan sekolah yang terakreditasi A dan menerapkan Kurikulum 2013 yang berarti SMA Negeri 3 Singaraja melakukan penilaian autentik. Berdasarkan hasil studi pendahuluan di SMA Negeri 3 Singaraja dengan cara mewawancarai guru kimia menunjukkan bahwa adanya hambatan-hambatan yang dihadapi oleh guru, salah satunya adalah dalam hal penilaian sikap. Dalam pelaksanaan penilaian sikap, guru masih mengalami kesulitan dikarenakan format penilaian yang terlalu banyak dan setiap guru harus melakukan pengamatan satu persatu siswa yang memiliki karakter, sifat, dan latar belakang yang berbeda-beda dengan waktu yang terbatas. Terdapat tiga cara penilaian sikap yaitu penilaian observasi, penilaian teman sejawat, dan penilaian diri hanya penilaian observasi yang dilakukan oleh guru kimia karena penilaian $\mathrm{KI}-1$ dan $\mathrm{KI}-2$ yang berhubungan dengan pendidikan karakter lebih dititikberatkan pada guru mata pelajaran Pendidikan Agama dan Pendidikan Kewarganegaraan.

\section{METODE}

Metode Penelitian ini menggunakan jenis penelitian fenomenolgis dengan pendekatan kualitatif. Subjek yang diteliti adalah guru kimia meliputi perencanaan, pelaksanaan, dan penilaian sikap sebagai dampak pengiring pembelajaran kimia. Data yang dikumpulkan meliputi data metode guru kimia dalam melaksanakan penilaian sikap sebagai dampak pengiring pada pembelajaran kimia dengan cara studi observasi, wawancara dan studi dokumentasi. Berikut matriks pengumpulan data.

\section{HASIL DAN PEMBAHASAN}

Data yang diperoleh dalam penelitian ini menggambarkan kendala yang dialami guru dalam penyelengaraan penialian sikap. semua guru wajib melakukan penilaian sikap hanya saja guru agama dan PPKn melakukan secara langsung dan tidak langsung sedangkan guru lain tetap melakukan namun mengarah ke $\mathrm{KD}$ dari $\mathrm{KI}-3$ dan $\mathrm{KI}-4$, dalam RPP $\mathrm{KI}-1$ dan $\mathrm{KI}-2$ tetap dicantumkan hanya saja $\mathrm{KD}$ dari $\mathrm{KI}-1$ dan $\mathrm{KI}-2$ tidak dicantumkan pada mata pelajaran kimia karena dibelajarkan secara tidak langsung dan memiliki dampak pengiring dari pembelajaran KD pada $\mathrm{KI}-3$ dan $\mathrm{KI}-4$. Pada perencanaan RPP, nilai karakter yang berkaitan dengan penilaian sikap dicantumkan semua nanti saat pembelajaran berlangsung akan dicatat sikap menonjol yang muncul dari siswa kemudian dipilih aspek sikap yang sesuai dan penilaiannya dilakukan dengan observasi menggunakan jurnal.

Guru menanamkan nilai-nilai sikap secara tidak langsung. Pendidikan karakter yang ditanamkan guru secara tidak langsung merupakan keteladanan guru yang sangat penting dalam memberikan contoh terhadap tindakan-tindakan yang baik, sehingga diharapkan menjadi panutan bagi peserta didik untuk mencontohnya, hal ini relevan dengan hasil penelitian yang dilakukan oleh Montonye, dkk., (2013) mengenai pengaruh pendidikan karakter di kelas menunjukkan bahwa guru merupakan faktor kunci kontribusi terhadap keberhasilan setiap program pendidikan karakter karena guru menerapkan kurikulum dan guru juga sebagai teladan bagi peserta didiknya. Sikap yang ditanamkan secara langsung oleh guru dalam pembelajaran memiliki hubungan dengan pendidikan karakter dan softskills. Berikut Tabel 1.1 mengenai hubungan butir-butir karakter yang muncul berdasarkan sikap spiritual, sikap sosial, pendidikan karakter dan softskills.

Tabel 1. Hubungan Sikap, Soft Skills, dan Karakter 


\begin{tabular}{llll}
\hline $\begin{array}{lll}\text { Butir- butir } \\
\text { Karakter }\end{array}$ & Sikap Spiritual & Pendidikan & Softskills \\
& Sosial & Karakter & \\
\hline Religius & $\sqrt{ }$ & $\sqrt{ }$ & $\sqrt{ }$ \\
Toleran & $\sqrt{ }$ & $\sqrt{ }$ & $\sqrt{ }$ \\
Disiplin & $\sqrt{ }$ & $\sqrt{ }$ & $\sqrt{ }$ \\
Jujur & $\sqrt{ }$ & $\sqrt{ }$ & $\sqrt{ }$ \\
Kerjasama & $\sqrt{ }$ & $\sqrt{ }$ & $\sqrt{ }$ \\
Tanggung & $\sqrt{ }$ & $\sqrt{ }$ & $\sqrt{ }$ \\
jawab & $\sqrt{ }$ & $\sqrt{ }$ & $\sqrt{ }$ \\
Percaya diri & $\sqrt{ }$ & $\sqrt{ }$ & \\
Santun & $\sqrt{ }$ & &
\end{tabular}

Hubungan sikap, soft skills, dan karakter memiliki keterkaitan yang memberi pengaruh baik terhadap pembentukan karakter anak di dalam pembelajaran. Saat pelaksanaan pembelajaran terdapat delapan nilai pendidikan karakter yang ditanamkan oleh guru yaitu religius, toleran, disiplin, jujur, kerjasama, tanggung jawab, percaya diri, dan santun. Hanya saja tidak semua nilai pendidikan karakter dinilai oleh guru. Sebagai seorang pendidik setiap guru wajib untuk memberikan pendidikan karakter untuk peserta didik agar pendidikan karakter mampu menjadi penggerak sejarah menuju Indonesia emas yang dicita-citakan, hal ini sejalan dengan hasil penelitian yang dilakukan oleh Agboola, dkk., (2012) ditunjukkan bahwa pendidikan karakter di dalam kelas menunjukkan bahwa hasil dari pendidikan karakter selalu mendorong dan menyiapkan pemimpin di masa mendatang secara pasti dan berkelanjutan. Dukungan dari orang tua, guru, dan staff sebagai pemangku kepentingan harus memberikan dorongan dan arahan kepada siswa untuk mengimplementasikan nilai-nilai baik itu dalam kehidupan mereka.

Penilaian sikap dalam pembelajaran kimia menggunakan observasi dengan menggunakan jurnal sedangkan penilaian teman sejawat dan penilaian diri sendiri tidak dilakukan karena hasil melalui pengamatan dengan hasil penilaian diri dan penilaian teman sejawat tidak sesuai. Apabila dalam jurnal tidak ada nama siswa yang tercatat maka sikap siswa diberi nilai $\mathrm{B}$, sedangkan bila menonjol sangat baik atau kurang maka akan diberi nilai $\mathrm{A}$ atau $\mathrm{C}$, nilai sikap dari guru kimia lalu diserahkan kepada wali kelas, dari wali kelas menyetor jurnal kepada guru BK, agama, dan PPKn untuk diolah sehingga muncul nilai sikap siswa. Setelah disimpulkan, nilai sikap siswa diserahkan ke wali kelas masing-masing untuk dibuatkan deskripsi.

Pengawasan pembelajaran kimia dilakukan oleh pihak internal sudah meliputi tahap evaluasi karena pengawas internal melakukan evaluasi kinerja guru terhadap aspek perencanaan, pelaksanaan, dan penilaian dan pengawas sekolah melakukan pada supervisi karena telah melakukan pemantauan pada aspek perencanaan, pelaksanaan, dan penilaian dengan memberikan saran, contoh, dan diskusi pelatihan. Hasil pengawasan didapatkan guru kimia mengalami kesulitan dalam melakukan penilaian karena terlalu banyak format penilaian yang ada sehingga untuk dilakukan workshop atau pelatihan setiap tahun ajaran baru untuk menyamakan format RPP, penilaian, dan hal lain yang terkait dengan pembelajaran.

\section{SIMPULAN DAN SARAN}

Dari Penilaian sikap di lapangan dilaksanakan dengan penilaian jurnal sedangkan penilaian diri dan penilaian antarteman tidak dilakukan. Aspek perencanaan, guru sudah mencantumkan aspek penilaian sikap dalam RPP dan lampiran penilaian sikap yaitu observasi, penilaian diri, dan penilaian antarteman. Pelaksanaan pembelajaran oleh guru mengajarkan aspek kognitif dan menyelipkan pendidikan karakter hanya saja dalam penilaian, guru hanya menggunakan penilaian observasi menggunakan jurnal sedangkan penilaian diri dan penilaian antarteman tidak dilakukan. Hal ini berimplikasi antara perencanaan dan pelaksanaan, yang sudah direncanakan dalam RPP tidak sesuai dengan pelaksanaan sehingga pengintegrasian pendidikan karakter tidak dapat dilakukan secara optimal. Penilaian sikap yang dilakukan hanya dengan penilaian observasi, sedangkan penilaian diri dan penilaian antarteman tidak dilakukan ini berimplikasi dengan nilai sikap yang dihasilkan sehingga berimplikasi dengan pendidikan karakter yang dirancang dalam 
Kurikulum 2013. Penilaian diri dan penilaian antarteman tidak dilakukan sehingga tidak bisa dilakukan konfirmasi dengan penilaian observasi.

Terdapat saran yang disampaikan tekait kendala yang dialami oleh guru dalam penyelenggaraan penilaian sikap sebagai berikut. (1) sebaiknya guru melakukan penilaian sikap sesuai dengan panduan yaitu penilaian observasi, penilaian diri sendiri, dan penilaian teman sejawat sehingga dari ketiga penilaian ini dapat mengonfirmasi sikap siswa dan pendidikan karakter yang ditanamkan dalam pembelajaran dapat dinilai serta dapat merubah sikap siswa menjadi lebih baik melalui keteladanan yang dicontohkan oleh guru. (2) diharapkan mengadakan workshop terkait cara penyusunan kegiatan pembelajaran yang mengintegrasikan sikap, cara penilaian sikap, dan proses integrasi sikap bagi guru supaya guru lebih jelas dan paham untuk melakukan proses pembelajaran yang mengintegrasikan sikap.

\section{DAFTAR RUJUKAN}

Agboola, A. \& K. C. Tsai. 2012. Bring Character Education into Classroom. European Journal of Educational Research. 1(2): 163-170.

Aiman, U. 2016. Evaluasi Pelaksana Penilaian Autentik Kurikulum 2013; Studi Kasus di Madrasah Ibtidaiyah Negeri Tempel Sleman Yogyakarta. Jurnal Pendidikan Madrasah 1(1): 55-62

Aminah, S. \& Y. N. Sari. 2016. Peningkatan Kompetensi Guru Kimia dalam Melaksanakan Kompetensi Inti Sikap Spiritual (KI-1) \& Sikap Sosial (KI-2) Melalui Model Tipe X. Seminar Nasional \& Pendidikan Kimia VIII.

Ariantini, P., I. N. Suandi \& I. M. Sutama. 2014. Implementasi Pengintegrasian Sikap Spiritual \& Sikap Sosial dalam Pembelajaran Bahasa Indonesia Berbasis Kurikulum 2013 di Kelas VII SMP Negeri 1 Singaraja. e-Journal Program Pascasarjana Undiksha. 1 (1): 34-41

Asmarawati, E., Riyadi \& I. Sujadi. 2016. Proses Integrasi Sikap Sosial \& Spiritual Dalam Pembelajaran Matematika Pada Siswa Kelas VII SMP Negeri di Kecamatan Purwodadi. Jurnal Elektronik Pembelajaran Matematika. 4(1): 58-69.

Elfindri, J. R., M. B. Wello, P. Tobing, F. Yanti, Zein, E. Eriyanti \& R. Indra. 2011. Soft Skills untuk Pendidik. Baduose Media.

Fitri, A. Z. 2012. Reinventing Human Character: Pendidikan Karakter Berbasis Nilai \& Etika di Sekolah. Yogyakarta: Ar- Ruzz Media.

Husamah, I. N. J. \& L. Chamisijatin. 2018. Implementasi Pendidikan Karakter dalam Pembelajaran IPA di SMPN XY Kota Malang. Jurnal Biotek 6 (1): 10-18

Kemendikbud. 2017. Panduan Penilaian oleh Pendidik \& Satuan Pendidikan untuk Sekolah Menengah Atas. Jakarta: Direktorat Jenderal Pendidikan Dasar \& Menengah.

Kosasih. 2014. Strategi Belajar \& Pembelajaran Implementasi Kurikulum 2013. Bandung: Yrama Widya

Laksana, S. 2015. Urgensi Pendidikan Karakter Bangsa di Sekolah. MUADDIB 5 (1) ISSN 2088-3390.

Lickona, T. 1992. Educating for Character: How Our School Can Teach Respect and Responsibility. New York: Bantam Books. 
Mazzola, J. W. 2003. Bullying in school: a strategic solution. Washington, DC: Character Education Partnership.

Montonye, M., S. Butenhoff \& S. Krinke. 2013. The Influence of Character Education on Positive Behavior in the Classroom. Masters of Arts in Education Research Papers 6: $1-9$

Muslich, M. 2011. Pendidikan Karakter Menjawab Tantangan Krisis Multidimensional.

Jakarta: Bumi Aksara.

Nurgiyantoro, B. \& A. Efendi. 2013. Prioritas Penentuan Nilai Pendidikan Karakter dalam Pembelajaran Sastra Remaja. Cakrawala Pendidikan 3 (1): 123-130

Peraturan Menteri \& Kebudayaan Republik Indonesia No. 81A Tahun 2013 tentang Implementasi Kurikulum.

Peraturan Menteri Pendidikan \& Kebudayaan No. 22 Tahun 2016 tentang Standar Proses Pendidikan Dasar \& Menengah.

Peraturan Menteri Pendidikan \& Kebudayaan Republik Indonesia No. 23 Tahun 2016 tentang Standar Penilaian Pendidikan.

Peraturan Menteri Pendidikan \& Kebudayaan Republik Indonesia No. 20 Tahun 2018 tentang Penguatan Pendidikan Karakter pada Satuan Pendidikan Formal Peraturan PresidenNo. 87 Tahun 2017 tentang Penguatan Pendidikan Karakter. Ratnawati, D. 2016. Kontribusi Pendidikan Karakter \& Lingkungan Keluarga terhadap Soft

Skills Siswa SMK. Jurnal Keguruan \& IImu Tabiyah 1(1) : 23-32.

Shoimin, Aris. 2014. Guru Berkarakter untuk Implementasi Pendidikan Karakter.

Yogyakarta: Gava Media. 